\title{
蛍光検出高速液体クロマトグラフィーによる 食品中のアスパルテームの定量
}

(昭和 60 年 5 月 9 日受理)

$\begin{array}{ll}\text { 玉瀬喜久雄 }{ }^{2} & \text { 北田善三*2 } \\ \text { 上田保 之 }{ }^{* 2} & \text { 竹下隆三*3 }\end{array}$

\section{Determination of Aspartame in Foods by High Performance Liquid Chromatography with a Fluorescence Detector}

\author{
Kikuo TAMASE*2, Yoshimi KITADA*2, Michiko SaSAKI*2, Yasuyuki UedA*2 \\ and Ryuzo TAKESHITA*3
}

(*2Nara Prefectural Institute of Public Health: 57-6, Ohmori-cho, Nara, Japan; ${ }^{*}$ School of Pharmaceutical Science, Toho University: 2-2-1, Miyama, Funabashi, Chiba, Japan)

\begin{abstract}
A sensitive method for the determination of aspartame (APM) in foods by high performance liquid chromatography with a fluorescence detector is described.

APM was extracted from a food sample with water. The extract was passed through a $\mathrm{C}_{8}$ column (LiChroprep RP-8, 40-63 $\mu \mathrm{m}, 1 \mathrm{~g}$ ). The column was washed with $0.05 \mathrm{M}$ acetate buffer solution ( $\mathrm{pH} 6.0$ ), then APM was eluted with a mixture of acetonitrile- $0.05 \mathrm{M}$ acetate buffer solution (3:7). APM in the eluate was derivatized with fluorescamine and injected onto a LiChrosorb RP-8 column; a mixture of acetonitrile- $0.05 M$ acetate buffer solution ( $\mathrm{pH} 6.0)(22: 78)$ was used as a mobile phase.

The recoveries of APM added to foods were more than $92 \%$. The detection limits of APM in liquid food and solid food were $2 \mathrm{ppm}$ and $4 \mathrm{ppm}$, respectively.
\end{abstract}

(Received May 9, 1985)

Key words: アスパルテーム aspartame; フルオレスカミン fluorescamine; 高速液体クロマトグ ラフィー high performance liquid chromatography; 蛍光検出器 fluorometric detertor

\section{緒 言}

合成甘味料のアスパルテーム (APM) は, 昭和 58 年 に我が国でも食品添加物として使用することが認めら れ，今後，さまざまな食品に使用されることが考えられ る. APM は人体への安全性が高いとされ，今のところ 使用基準は設定されていない.しかし，フェニルケトン 㽷症の患者には APM の摄取が好ましくないことや, APM の分解物として, メタノールやジケトピペラジン などが生成する ことから APM の食品への使用実態

\footnotetext{
*1 高速液体クロマトグラフィーによる食品添加物の 分析 (第 5 報)

*2 奈良県衛生研究所：奈良市大森町 57-6

*3 東邦大学薬学部: 千葉県船橋市三山 2-2-1
}

を正しく把握する必要があり，簡便で精度のよい定量法 の開発が望まれている.

食品中の APM の定量法として, アミノ酸アナライザ 一による方法 ${ }^{2}$,3) 及び高速液体クロマトグラフ (HPLC) ${ }^{4) ~ 8)}$ による方法が報告されているが，アミノ酸 アナライザーによる方法は日常分析法として，あまり一 般的でなく, HPLC 法は, いずれも UV 検出器を用い ていることから, 定量に際して，他の共存物質の影響を 受けやすく, また, 高い測定感度を得るためには HPLC へ試料溶液の多量負荷が必要となる.これらの問題を解 決するため, 今回, APM を蛍光試薬にてラベル化し, 蛍光検出 HPLC にて定量する方法を検討したところ良 好な結果が得られたので報告する。 


\section{実 験方法}

\section{1. 試料}

以下の食品 20 検体を試料に供した。

1）液体食品：清涼飲料水 (4 種類), コーヒ飲料, 乳 酸菌飲料, しょう油

2）固形食品：粉末清涼飲料，チューインガム，フル ーツゼリ一, 承菓子, みそ, 漬物類 (4 種類), プリン

3）脂肪性食品：チョコレート，アイスクリーム，ホ イップクリーム

\section{2. 試薬及び器具}

0.5 M 酢酸塩緩衝液 (Ac. B. S.): 0.5 M 酢酸ナトリウ ム溶液に $0.1 \mathrm{~N}$ 水酸化ナトリウム溶液を加えて $\mathrm{pH} 6.0$ に調整した.

$0.05 M$ Ac. B. S.: $0.5 M$ Ac. B.S. を水にて 10 倍希 釈した.

$0.2 M$ ホウ酸塩緩衝液：ホウ酸 $2.47 \mathrm{~g}$ を水約 $180 \mathrm{ml}$ に溶かしてこれに $1 N$ 水酸化ナトリウム溶液を加えて pH 7.5 とし, さらに水を加えて全量 $200 \mathrm{ml}$ とした.

フルオレスカミンーアセトン溶液：フルオレスカミン (Roche 製) $25 \mathrm{mg}$ をアセトンに溶かして全量 $10 \mathrm{ml}$ と した.

APM 標準溶液: APM (Aldrich Chem. 製) $100 \mathrm{mg}$ を，あかじめ $0.001 N$ 塩酸を用いて $\mathrm{pH} 4.0$ に調整 した水に溶かして全量 $100 \mathrm{ml}$ とし，これを標準原液と した。標準原液を適宜水にて希釈し，標準溶液とした。

$\mathrm{APM}$ 分離用カラム：分取高速液体クロマトグラフィ 一用充て儿剂 LiChroprep RP-8 (40 63 $\mu \mathrm{m}) 1 \mathrm{~g}$ を内 径 $10 \mathrm{~mm}$ のカラム管に詰め, メタノール $10 \mathrm{ml}$, 次い で水 $20 \mathrm{ml}$ で洗浄した後, 使用直前に $0.05 M$ Ac.B.S. $5 \mathrm{ml}$ を流して用いた。

\section{3. 装置}

高速液体クロマトグラフ：(株) 島津製作所製 LC-3A 蛍光検出器：(株) 島津製作所製 RF-510

\section{4. 操 作}

\section{1 試料溶液の調製}

a) 液体食品：試料 $2 \mathrm{~g}$ に $0.5 M$ Ac. B. S. $1 \mathrm{ml}$, 水 $7 \mathrm{ml}$ を加党て振りまぜた後, $\mathrm{APM}$ 分離用カラムに負 荷する. 次に, カラムを $0.05 M$ Ac. B. S. $10 \mathrm{ml}$ で洗浄 した後, アセトニトリル $-0.05 M$ Ac. B.S. (3:7) の混合 溶液で溶出して最初の $5 \mathrm{ml}$ を分取し, 試料溶液とした。

b) 固形食品：試料 $10 \mathrm{~g}$ に水を約 $30 \mathrm{ml}$ 加えてホモ ジナイズした後，さらに水を加えて全量 $100 \mathrm{ml}$ とする. 次に, 東洋濾紙 No. 2 の口紙にてろ過を行い, ろ液の $10 \mathrm{ml}$ に $0.5 \mathrm{M}$ Ac. B.S. $1 \mathrm{ml}$ を加えて振りまぜた後, 分離用カラムに負荷する. 以後は液体食品と同様に操作 した。

c) 脂肪性食品：試料 $5 \mathrm{~g}$ を $50 \mathrm{ml}$ 共栓付遠沈管に 採取し，これに水約 $10 \mathrm{ml}$ を加え，ガラス棒にてよくか きまぜ, 約 2 分間超音波をかける. その後, エーテル 25
Table 1. Operating Conditions of HPLC

\begin{tabular}{ll}
\hline \hline Column: & LiChrosorb RP.8 $(5 \mu \mathrm{m})$ \\
& $4 \mathrm{~mm}$ i.d. $\times 25 \mathrm{~cm}$ \\
Column temp: & $40^{\circ} \mathrm{C}$ \\
Mobile phase: & Acetonitrile-0.05 $M$ Sodium \\
& acetate (pH 6.0) (22:78) \\
Flow rate: & $0.7 \mathrm{ml} / \mathrm{min}$ \\
Detector: & FLD; Ex $=390 \mathrm{~nm}$ \\
& $\mathrm{Em}=480 \mathrm{~nm}$ \\
Sample size: & $5 \mu l$ \\
\hline
\end{tabular}

$\mathrm{ml}$ を加えて 5 分間振とうし，遠心分離してェーテル層 を除去する．再びェーテル $25 \mathrm{ml}$ を加えて同様に操作 し，水層に残っているエーテルを減圧下，完全に留去し た後, $50 \mathrm{ml}$ のメスフラスコへ移し, 水を加えて全量 50 $\mathrm{ml}$ とする. 次に, 東洋濾紙 No. 2 の口紙にてろ過し, ろ液の $10 \mathrm{ml}$ に 0.5 M Ac. B.S. $1 \mathrm{ml}$ を加え, 振りま ぜた後, 分離用カラムに負荷する，以後は液体食品と同 様に操作して試料溶液を調製した。

\section{2 定 量}

試料溶液 $50 \mu 1$ をマイクロシリンジにて試験管に採取 し,これに $0.2 M$ ホウ酸塩緩衝液 $2 \mathrm{ml}$ を加えた後, サ ーモミキサーでミキシングしながらフルオレスカミンー アセトン溶液 $200 \mu 1$ をマイクロシリンジにて迅速に加 え, 澄明な溶液が得られるまで, さらにミキシングを続 けて HPLC 用試験溶液とした. HPLC の測定条件は Table 1 に示した.

\section{結果及び考察}

\section{APM 分離用カラムによる前処理}

試料が炭酸飲料や水菓などの場合は APM 分離用カ ラムによる前処理を省いても定量が可能であったが，乙 ょう油やみそなどの場合はアミノ酸類を多く含むため, これらが蛍光試薬のフルオレスカミンと反応して HPLC での測定時に妨害ピークとして出現した. この ため, 主にアミノ酸類の除去を目的として, 今回の分離 用カラムによる前処理法を検討した.

\section{1 洗浄液の検討}

APM を含む試料液を分離用カラムに負荷した後, カ ラムの洗浄を水で行うと回収率が低下したため, 水の代 わりに Ac. B.S. を用いたところ，Fig. 1 に示すよう に，0.02M 以上の濃度で回収率がほぼ $100 \%$ となった. このことから今回, APM を捕集したカラムの洗浄液に は $0.05 M$ Ac. B.S.を用いた. なお，試料にはオレン ジジュース，しょう油，たくあん漬を用いて検討を行っ た。

\section{2 溶 離 液}

分離用カラムから APM の溶離液として, アセトニト リルと $0.05 M$ Ac. B. S. の混合溶液を用いた. 両者の 比が 2:8, 3:7 及び 4:6 としたとさの APM の溶出パタ ーンは Fig. 2 に示すと扣りとなり, 混合比が $3: 7$ 及び 
Table 2. Recoveries of Aspartame added to Foods

\begin{tabular}{|c|c|c|c|c|c|}
\hline Sample & $\begin{array}{l}\text { Added } \\
(\mu \mathrm{g} / \mathrm{g})\end{array}$ & $\begin{array}{c}\text { Recovery* } \\
(\%)\end{array}$ & Sample & $\begin{array}{l}\text { Added } \\
(\mu \mathrm{g} / \mathrm{g})\end{array}$ & 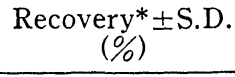 \\
\hline \multirow[t]{2}{*}{ Fruit drinks } & 100 & $98.7 \pm 2.2$ & Pudding & 100 & $97.7 \pm 1.7$ \\
\hline & 500 & $95.9 \pm 1.8$ & & 500 & $98.0 \pm 1.3$ \\
\hline \multirow[t]{2}{*}{ Coffee drinks } & 100 & $94.5 \pm 2.1$ & Fruit jelly & 100 & $93.3 \pm 2.5$ \\
\hline & 500 & $99.5 \pm 1.8$ & & 500 & $98.2 \pm 0.6$ \\
\hline \multirow[t]{2}{*}{ Lactic beverage } & 100 & $99.6 \pm 0.8$ & Ice candy & 100 & $94.5 \pm 1.6$ \\
\hline & 500 & $99.8 \pm 2.3$ & & 500 & $99.7 \pm 1.1$ \\
\hline \multirow[t]{2}{*}{ Soy sauce } & 100 & $98.9 \pm 3.2$ & Miso & 100 & $93.3 \pm 1.6$ \\
\hline & 500 & $97.5 \pm 0.6$ & & 500 & $93.6 \pm 1.2$ \\
\hline \multirow[t]{2}{*}{ Pickles } & 100 & $94.5 \pm 2.5$ & Chocolate & 100 & $99.8 \pm 3.1$ \\
\hline & 500 & $99.8 \pm 0.7$ & & 500 & $99.3 \pm 0.6$ \\
\hline \multirow[t]{2}{*}{ New fruit candy } & 100 & $98.4 \pm 1.6$ & Ice cream & 100 & $95.2 \pm 3.4$ \\
\hline & 500 & $95.3 \pm 1.9$ & & 500 & $92.6 \pm 1.9$ \\
\hline \multirow[t]{2}{*}{ Chewing gum } & 100 & $92.2 \pm 0.6$ & Whip cream & 100 & $97.7 \pm 1.5$ \\
\hline & 500 & $96.6 \pm 1.5$ & & 500 & $95.0 \pm 2.2$ \\
\hline
\end{tabular}

* Average of four trials

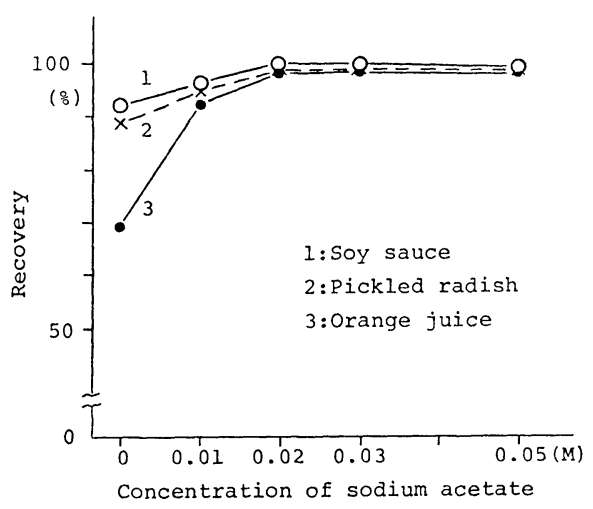

Fig. 1. Relation between recovery rate and concentration of sodium acetate

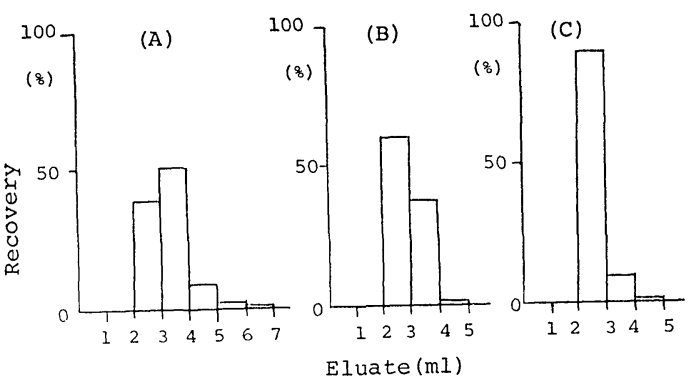

Fig. 2. Elution patterns of aspartame from $\mathrm{C}_{8}$ column

(A) Eluent: $\mathrm{CH}_{3} \mathrm{CN}-0.05 \mathrm{M \quad \textrm {CH } _ { 3 } \mathrm { COONa }}$ (2:8); (B) Eluent: $\mathrm{CH}_{3} \mathrm{CN}-0.05 \mathrm{MCH}_{3}$ COONa (3:7); (C) Eluent: $\mathrm{CH}_{3} \mathrm{CN}-0.05 \mathrm{M}$ $\mathrm{CH}_{3} \mathrm{COONa}(4: 6)$

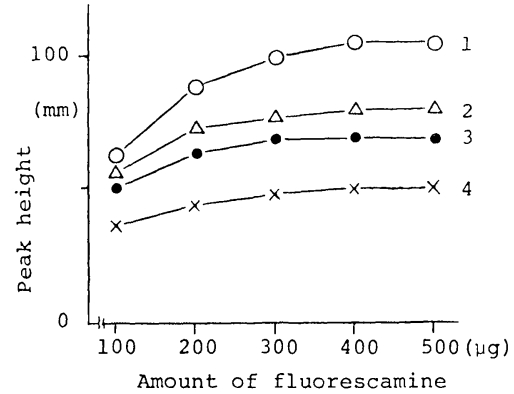

Fig. 3. Relation between amount of fluorescamine and fluorescence intensity 1: soy sauce; 2 : orange juice; 3 : chocolate; 4 : pickled radish

4:6 の場合に溶出液 $5 \mathrm{ml}$ でほぼ 100\% の溶出率となっ た.

2. フルオレスカミンによる蛍光ラベル化 2.1 反応と $\mathrm{pH}$ との関係

$\mathrm{APM}$ とフルオレスカミンを反応させる際の至適 $\mathrm{pH}$ について調べたところ, ホウ酸塩緩衝液の $\mathrm{pH}$ が 7.3〜 8.0 で最も高率に反応生成物が得られた. 従って標準操 作法では，ホウ酸塩緩衝液の $\mathrm{pH}$ を 7.5 とした. ところ で，APM はアルカリ性水溶液中では分解しやすい9） 言われているため, APM 標準溶液 $50 \mu 1$ に $\mathrm{pH} 7.5$ の ホウ酸塩緩衝液を加えて放置したところ，1時間以内で は，ほとんど分解せず安定であった。また，フルオレス カミンと反応させた後の蛍光誘導体は, かなり長時間安 定しており，7時間を経過しても，ほとんど変化はみら れなかった。 

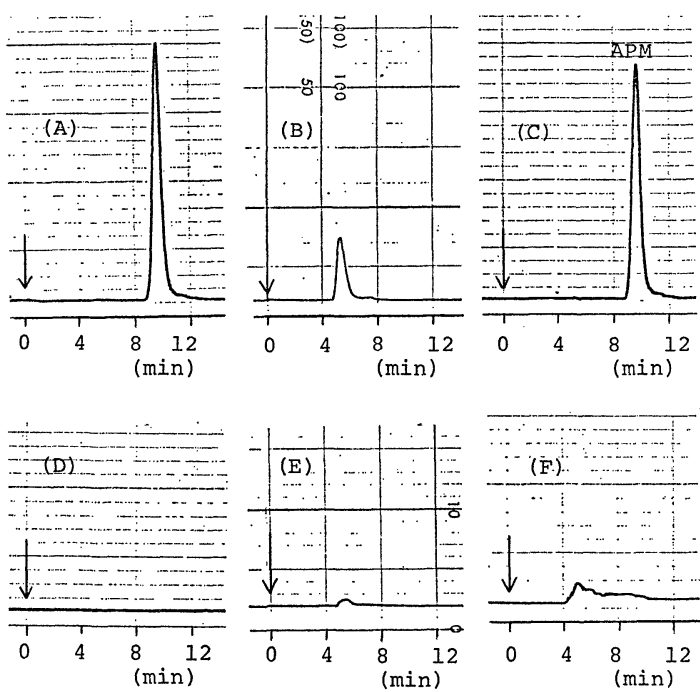

Fig. 4. Liquid chromatograms of prepared solution obtained from various foods

(A) standard, (B) apple Juice, (C) cola, (D) candy, (E) fruit jelley, (F) chocolate

\section{2 フルオレスカミン添加量}

試料溶液 $50 \mu 1$ 中に含まれる APM を完全に蛍光 ベル化するために必要なフルオレスカミン量を調べた. その結果, Fig. 3 に示すよらに各試料ともフルオレスカ ミン量が $400 \mu \mathrm{g}$ 以上で APM 蛍光誘導体のピーク高は 一定となった. このことから，フルオレスカミン添加量 は $400 \mu \mathrm{g}$ で十分と思われるが，余裕をみて $500 \mu \mathrm{g}$ と した.

なお，試料にはたくあん漬，チョコレート，オレンジ ジュース及びしょう油に APM を 0.5 1.0 mg/g 添加 したものを用いた。

\section{HPLC 条件及び検量線}

HPLC のカラムには逆相分配系の LiChrosorb RP-8 移動相としては, アセトニトリル $0.05 M$ 酢酸塩緩衝液 (22:78) を用いた。 そのとき得られたクロマトグラムを Fig. 4 に示したが, 今回検討したすべての食品で定量を 妨害するピークは出現しなかった.

ピーク高法による検量線は APM として $0.05 〜 180$ $\mu \mathrm{g} / \mathrm{tube}$ で良好な直線性を示した. 検出限界は液体食品 $2 \mathrm{ppm}$, 固形食品及び脂肪性食品が $4 \mathrm{ppm}$ であり, 従来 の UV 吸収-HPLC 法と比較すると HPLC へは少量の 負荷量でも高い測定感度が得られた。

\section{4. 添加回収実験}

各試料に $100 \mathrm{ppm}$ 及び $500 \mathrm{ppm}$ に相当する APM
を添加して本法に従って操作し，回収率を求めた。 その 結果は Table 2 に示すと打りで, 液体食品 94.5 $99.8 \%$, 固形食品 $92.2 \sim 99.8 \%$, 脂肪性食品 $92.6 \sim$ 99. $8 \%$ と良好な結果が得られた。 また，それぞれの回収 率に拈ける標準偏差 (SD) は 0.6〜3.4 であり, 精度的 にもほぼ満足できる結果が得られた.

\section{まとめ}

APM を蛍光誘導体化し，HPLC にて定量する方法を 検討した.

蛍光試薬としてはフルオレスカミンを用いたが， APM とは簡易かつ迅速に反応し, 生成した蛍光誘導体 の安定性も高かった。しかし，フルオレスカミンは第一 級アミノ基を有するものと特異的に反応することから， アミノ酸類などが HPLC での測定を妨害するおとれが ある.このため, APM 分離用カラムによる前処理を検 討したところ，これらを除くことができた.

HPLC のカラムには逆相系の LiChrosorb RP-8, 移 動相にアセトニトリルー水系を用いたが，検討したすべ ての食品で, 共存物質による影響はみられず, また，従 来の方法と比較して HPLC へは少量の負荷量でも高い 測定感度が得られた.

文献

1）荒井綜一：食品工業. 25(24)，49～61 (1982).

2）石渡昭男，鈴木幸允： 食衛誌。 16, 420 421 (1975).

3) 西島基弘, 冠 政光, 高橋尚子, 上村 尚, 中里 光男, 渡利優子, 木村康夫：同上 $17,78 \sim 84$ (1976).

4) Gaylord, Lew, F., Anthony, D., Edward, P. K. Lau: J. Assoc. Off. Anal. Chem. 59, 1048 1050 (1976).

5) Norma, G. W., Darrell, D. B.: ibid. 67, 510 513 (1984).

6) Daniel, H. D., Frank, L. J. Jr., Charles, R. W., Thomas, F.: ibid. 67, 513 515 (1984).

7) Theodore, A. T.: ibid. 67, 745 747 (1984).

8) 井部明広, 斉藤和夫, 中里光男, 菊地洋子, 藤沼 賢司, 直井家壽太, 二島太一郎：食衛誌. 26,1 6 (1985).

9) Furda, I., Malizia, P. D., Kolor, G. M., Vernieri, J. P.: J. Agric. Food Chem. 23, 340 343 (1975). 